\title{
ARE BIOLOGICAL EFFECTS OF SHOCK WAVES CAUSED BY FREE RADICALS?
}

\author{
Dierk Suhr, Franz Brümmer and Dieter F. Hülser
}

Abt. Biophysik, Biologisches Institut, Universität Stuttgart

Pfaffenwaldring 57, D-7000 Stuttgart 80, Fed. Rep. Germany

Stone fragmentation in extracorporeal shock wave lithotripsy as well as accompanying tissue damage are attributed to cavitation. We attempted to demonstrate and localize the occurrence of cavitation in cell-free solutions and MGH-U1 cells using sensitive dyes for the detection of cavitation-generated free radicals.

Keywords: shock wave lithotripsy; cavitation; free radicals

\section{INTRODUCTION}

Extracorporeal shock wave lithotripsy of urinary stones has replaced open surgery nearly completely. However, side effects like hemorrhages and hematomas occur in vivo $(1,2)$ which are mainly attributed to cavitation, i.e. the growth and collapse of bubbles in liquids exposed to tensile stresses. In vitro, eukaryotic cells were damaged or destroyed in a dose dependent manner when treated in suspension (3). Since this damage is not related to the origin of cells, and is similiar for normal and malignant cells (4), it probably will have a physical and not a biological reason. Intracellular damage of cellular organelles after shock wave treatment $(5,6)$ may be caused by cavitation. During the adiabatic collapse of cavitation bubbles, temperature rises up to several thousand $\mathrm{K}$, causing the formation of free radicals. We investigated the occurrence of cavitation using radical sensitive dyes, suitable for extra- and intracellular measurements, as indirect indicators for cavitation.

\section{MATERIAL \& METHODS}

As a control, we used fluorescein diacetate (FDA, Sigma), which becomes fluorescent after deacetylation and is insensitive to oxidation by free radicals. Sensitive dyes were dichlorofluorescin diacetate (7) (DCFH-DA, Serva) and hydroethidine (8) (Polyscience), which become fluorescent after oxidation. DCFH-DA accumulates intracellularly after deacetylation to dichlorofluorescin (DCFH) and becomes fluorescent after oxidation to dichlorofluorescein (DCF). Hydroethidine is trapped inside the cells after oxidation to the intercalating dye ethidium. To investigate the appearance of extracellular cavitation and radicals, $1 \mu \mathrm{M}$ DCFH-DA or FDA was hydrolyzed to DCFH or fluorescein by incubation for $30 \mathrm{~min}$ with carboxyl esterases 
(Sigma; final activity approx. $1 \mathrm{unit} / \mathrm{ml}$ ) and then treated with shock waves. Hydroethidine was treated with shock waves at a concentration of $160 \mu \mathrm{M}$. This higher concentration was necessary because of the weak fluorescence without intercalation in DNA (9). For intracellular investigations, we used a human bladder carcinoma line, MGH-U1 $(10,11)$, growing as monolayers at $37^{\circ} \mathrm{C}$ and $8 \% \mathrm{CO}_{2}$ in RPMI 1640 medium (Boehringer Mannheim), supplemented with $10 \%$ fetal calf serum, $24 \mathrm{mM} \mathrm{NaHCO}_{3}$, and antibiotics. Single cell suspensions $\left(2-3 \cdot 10^{5}\right.$ cells/ml), obtained by trypsinization and mechanical dispersion in phosphate buffered saline, were transferred into $4.5 \mathrm{ml}$ polyethylene pipettes (Brand) and treated with shock waves. The pipette ball was submerged in the partially degassed $(2.1-3.3 \mathrm{mg} \mathrm{O} / \mathrm{l})$ waterbath of an experimental spark gap lithotripter XL-1 (Dornier Medizintechnik) and positioned into the target focus of the brass semi-ellipsoid. Suspended MGH-U1 cells and dye solutions were kept at $21^{\circ} \mathrm{C}$ and exposed to shock waves (125-750) at a pulse repetition frequency (PRF) of 1 or $8 \mathrm{~Hz}$ and a generator voltage setting of $18 \mathrm{kV}$. Controls were kept at $21^{\circ} \mathrm{C}$ for the time necessary for shock wave treatment. Electrodes were not used prior to the first 50 and after 1500 shock waves. The final dye concentration in cell suspensions was $1 \mu \mathrm{M}$ for DCFH-DA (stock solution $10 \mathrm{mM}$ in dimethylformamid [DMF, Sigma]) and for FDA (stock solution $0.5 \mathrm{mM}$ in acetone) or $16 \mu \mathrm{M}$ for hydroethidine (stock solution $63.5 \mathrm{mM}$ in DMF). For shock wave treatment, cell suspensions stained with DCFH-DA or FDA were incubated for $30 \mathrm{~min}$ at $37^{\circ} \mathrm{C}$ in the dark, hydroethidine-stained cells were treated $10 \mathrm{~min}$ after addition of the dye. The fluorescence of shock wave treated cells and controls was determined by flow cytometry (FACS-Analyzer, Becton-Dickinson). The fluorescence of dye solutions was detected with a spectrofluorometer (LS-3B, Perkin-Elmer). For each experiment, a relative fluorescence is given by comparing the shock wave treated sample with the untreated control.

\section{RESULTS}

In cell-free dye solutions, the radical insensitive fluorescein showed no change in fluorescence $(0.99 \pm 0.01)$ even after 500 shock waves at a PRF of $8 \mathrm{~Hz}$. Using DCFH, we found an increase in fluorescence of the oxidation product DCF (fig. 1) with increasing number of shock waves and PRF, indicating cavitation-generated free radicals. The same results were found using solutions of hydroethidine (fig. 2), however, less fluorescence was observed depending on the lack of intercalation in cellfree solutions. On the basis of these results, we treated DCFH-DA- and hydroethidinestained MGH-U1 cells with different numbers of shock waves at PRFs of 1 or $8 \mathrm{~Hz}$. For the dye DCFH-DA, we found a decrease in fluorescence at both PRFs (data not shown), which must be attributed to a dye leakage through transient ruptures of the cell membrane. This problem was bypassed using hydroethidine, where the oxidation product ethidium binds to the DNA: in spite of the leakage, a slight but significant increase in intracellular fluorescence was found (fig. 3). 

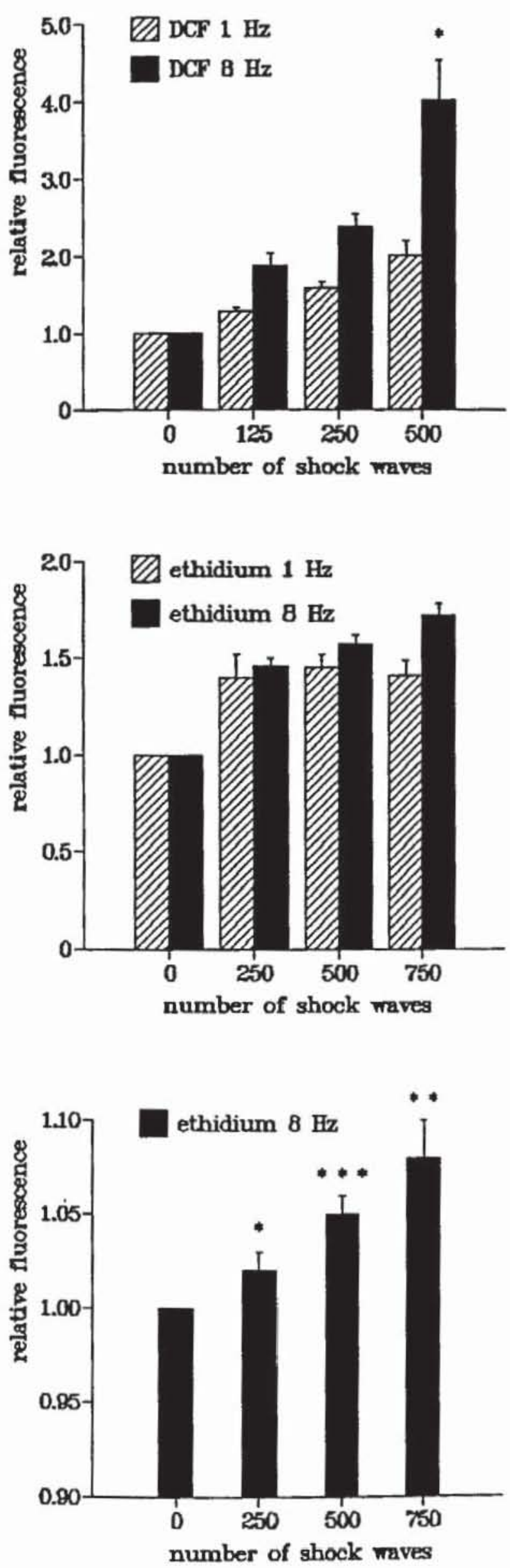

fig. 1: Cell-free investigation using dichlorofluorescin(DCFH):dose and frequency dependent increase in fluorescence of the oxidation product dichlorofluorescein (DCF) after shock wave treatment, indicating cavitationgenerated free radicals. Mean \pm standard error of the mean.

* $\alpha<0.05$ vs. $500 \mathrm{sw} / 1 \mathrm{~Hz}$ (two-sided U-test). fig. 2: Cell-free investigation using hydroethidine: dose and frequency dependent increase in fluorescence of the oxidation product ethidium after shock wave treatment, indicating cavitation-generated free radicals. Mean \pm standard error of the mean. fig. 3: Generation of intracellular free radicals after shock wave treatment of hydroethidine-stained MGH-U1 cells: dose dependent increase in intracellular fluorescence of the oxidation product ethidium. Mean \pm standard error of the mean.

${ }^{*} \alpha<0.05^{* *} \alpha<0.02$

$* * * \alpha<0.01$ vs. control (two-sided U-test). 


\section{DISCUSSION}

The appearance of cavitation (12) as well as the generation of free radicals in water $(13,14)$ during extracorporeal shock wave lithotripsy is not questioned. Although cavitation was often assumed as a mechanism for stone fragmentation (15) and tissue damage (16), shock wave generated intracellular cavitation has not been demonstrated, but would explain the intracellular damages in otherwise intact shock wave treated cells which were observed after treatment of cell suspensions $(5,6)$. Using fluorescent dyes, we now successfully prove the production of cavitation generated free radicals not only in cell-free solutions but also intracellularly.

Both, hydroethidine and DCFH detect free radicals which must be attributed to shock wave induced cavitation, whereas the fluorescence of radical insensitive fluorescein remains unaffected by shock waves. The decrease in cellular fluorescence after shock wave treatment with both sensitive and insensitive dyes was caused by a transient permeabilization of the cell membrane. The decrease was similiar for both dyes at $1 \mathrm{~Hz}$ but differed at $8 \mathrm{~Hz}$ (data not shown), indicating a partially compensation of the dye loss through additional formation of the oxidation product of the sensitive dye by free radicals. Because these changes in membrane permeability made the results difficult to interprete, we focussed on hydroethidine, where the oxidation product ethidium intercalates into the DNA and is thus trapped within the cell. Indeed, using hydroethidine we were able to detect an increase in intracellular fluorescence, indicating cavitation-generated intracellular free radicals, which may be caused by intracellular cavitation.

There is no doubt that free radicals occur after shock wave treatment both extra- and intracellularly. Free radicals cause severe tissue damage leading to a release of cytoplasmic proteins, e.g. Tamm-Horsfall-protein (17), which was also measured after shock wave lithotripsy (18). Therefore, the effect of scavengers of free radicals, e.g. ascorbic acid will be investigated.

\section{REFERENCES}

(1) Lingeman JE, McAteer JA, Kempson SA, Evan AP Urol Clin North Am (1988) 15 507-514

(2) Brümmer F, Bräuner Th, Hülser DF World J Urol (1990) $8224-232$

(3) Brümmer F, Brenner J, Bräuner Th, Hülser DF Ultrasound in Med \& Biol (1989) 15 229-239

(4) Brümmer F, Suhr D, Hülser DF J Endourol (1990) 4 (Suppl. 1) S60

(5) Russo P, Mies C, Huryk R, et al. J Urol (1987) 137 338-341

(6) Bräuner Th, Brümmer F, Hülser DF Ulltrasound in Med \& Biol (1989) 15 451-460

(7) Keston AS, Brandt R Anal Biochem (1965) 111.5

(8) Thomas G, Roques B FEBS Lett (1972) 26 169-175

(9) LePecq JB, Paoletti C J Mol Biol (1967) 27 87-106

(10) Evans DR, Irwin RJ, Havre PA, et al. J Urol (1977) $117712-719$

(11) Masters JRW, Hepburn PJ, Walker L, et al. Cancer-Res 46 3630-3636

(12) Coleman A, Saunders JE, Crum LA, Dyson M Ultrasound in Med \& Biol (1987) 13 69-76

(13) Henglein A, Gutiérrez M, Ulrich R Int J Radiat Biol (1988) 54 123-126

(14) Morgan TR, Laudone VP, Heston WDW, et al. J Urol (1988) 139 186-189

(15) Delius M, Brendel W Naturwissenschaften (1988) 75 200-201

(16) Fischer N, Muller HM, Gulham A, et al. J Endourol (1988) 2215-220

(17) Bakris GL, Gaber AO, Jones AD Radiology (1990) 175 57-60

(18) Wilbert DM, Strohmaier WL, Flüchter SH, Bichler KH Invest Urol (1989) 3 249-253 